\title{
Deschooling from Religious Education in Islamic Republic of Iran: Possibility and Necessity?
}

\author{
Seyed Mahdi Sajjadi', Sareh Ansari*2 \\ ${ }^{1}$ Assistant Professor of philosophy of education in Tarbiat Modares University. \\ 2M.A. In Philosophy of education
}

Corresponding Author E-mail: sarehansari2@gmail.com

Received: 24 October 2018, Revised: 05 December 2018, Accepted: 20 December 2018

\section{ABSTRACT}

Nowadays negative implications of Globalization, the crisis of values, crisis of media, consumerism, and lack of cultural identification, impatience in the face of religion, virtual identification and loss of religious and traditional values are the main challenges confronting students. Besides transfer of knowledge, schools are responsible for educating the graduates, too. It means that it should invest in flourishing all existential dimensions of students including intellectual, emotional, social, spiritual, and moral dimensions and care for their education and productivity. Now this question arises is that since religious education is a process accomplished through granting vision, genuine and practical obligation to the person, in harmony with his nature and far from force and pressure, in order to gain this- and other-worldly prosperity, can the school undertake this important responsibility or not and in the case of disability to fulfill this duty, should religious education be deschooled; i.e. the mission of religious education should be assigned to institutions other than school or not? The findings of this investigation show that religious education doesn't have desirable situation and the new generation doesn't receive the religious thoughts and behaviors as is qualified. Teachers use grade and other quantitative indices to teach values and morality and evaluate the progress in religious education of students; this results in duality of the student's identity, personality and behavior, because they are not motivated internally to learn religious issues. On the other hand, in Islamic societies, the administrators and politicians cannot be irresponsible for the religious education of members of their society. According to the doctrines of the true religion, Islam, governors and politicians are obliged to attempt to accomplish this affair, so ministry of education in Iran as a public institution has taken the charge of this affair and schools are charged with delivering religious and divine education to the students and the necessity of deschooling the religious education is denied in Islamic republic of Iran and since our formal education is directly governed by the government and is mentioned in national document of school curriculum and also the document of fundamental transition in education, the objective of education is to educate a religious and committed human being, 
we may not separate the religious education of students from school. So the possibility of deschooling from religious education in Iran is denied, too. But the tenure of government and formal education relating to religious education is conditional upon conditions, that if accomplished, the tenure will be permitted. In this article these conditions are indicated in detail.

Keywords: Education, Religion, Religious Education, The Possibility and Necessity of Religious Education, Deschooling.

\section{Introduction}

The main issue in this article is the possibility and necessity of deschooling from religious education in Islamic Republic of Iran's education system. In other words, this article is going to answer the following fundamental questions that considering the relations between educational system and political structure and domination of government on educational system and as a result the educational and religious harms stemming from these relations, deschooling from religious education in Iran, is necessitated? May the formal institution of education and training (public schools), in real sense, be and is qualified to be guardian of religious training in Iran educational system? Maybe we deschooling religious education or we ought to yield it to the informal institutions? About the mission of Islamic education in schools, have Iran schools really fulfilled their mission? If the answer is yes, then why mental and behavioral situation of our youth and graduates doesn't suggest the success of our schools in fulfilling this mission? (Karimi, 2002,) In Islamic view, the human being is the caliph and deputy of God on the earth who has divine features. His existence dimensions include physical, intellectual, emotional, spiritual and unworldly to which Islam has paid special attention and has ignored neither of them. But spiritual and unworldly dimensions are regarded as very important. Our concern in this article is that may really school educate such a human being? Could schools in Iran attempt to educate a religious human, in the real sense, through adopting rational methods and approaches or they have been deprived in their important mission in the shadow of wrong and irrational approaches and imposition of political and ideological goals outside of school?

\section{The Possibility of Religious Education}

Some believe that faith in issues like religious education, is kind of retrogressions and fundamentalism and shows uncomprehending the new world and principles and relations dominated on it. So, considering this perspective, religious education is an impossible issue and when appeared and occurred, has retrogressive, unscientific and reactionary nature, is limited and so is impossible and contradictory.

Some other educational trainers believe religious, moral and valuable education and training is ensured by some dishonest, insincere, artificial and unnatural behavior. In other words, building civil and democratic society is contrasted with accomplishing values and moral education, especially moral education and religious values. It means moral education which may be the result of religious education is known as lack of individual freedom. Dewey declares religious education as a 
barrier in front of building a democratic society (Dewey, 1916). Some believe there is not required consistency and harmony between real methods of moral education and its objectives, so moral and value education leads to instillation. Some others believe that moral and value education is not based on moral change principles (Marzooghi, 1997).

Others question the possibility of accomplishment of value and religious knowledge, through discussing cognitive knowledge issues, and doubt if religious and value knowledge may be achieved through learning and education.

Francis Bacon (1561-1626 A.D.), the founder of scientific movement and the most famous figure of secular realists, names religion and faith as one of four idols which contaminates mind and hinders the progress of science with its dogmatic hypotheses. Bacon thinks knowledge is power, and claimed that through attaining knowledge, we confront the problems and pressures surrounding us more efficiently and knowledge is attained by reliable research method and induction (Malssen, 2015). John Locke (1632-1704 A.D.) is another notable pioneer of new realist thinking, who while supporting Bacon's experience-orientation and that the correctness of thinking is recognizable with experience, rejects intrinsic thought. He draws a line over Plato's Estezkar theory and nature theory.

Considering features like secularity or irreligiousness of education in today world and especially in West, as a result, religious education is excluded from the main and formal curriculums of education, because it is argued that religion and religious doctrines belong to tradition which contradicts wisdom. Religion will be eliminated from the formal and essential curriculum of education ministry because it is argued that religion and religious teachings belong to tradition which contradicts with wisdom- beliefs. Religion is eliminated from active and effective presence in social scene and is defined in the limitations of individual life. This perspective is, consciously or unconsciously, considered in the agenda of different countries and societies that reject religion and values from people's lives.

Mottahari criticizes the above realities and calls western culture and civilization the culture of forgetting oneself and world consciousness and believes that as the West awareness from the world increases, it forgets itself more and this is the main reason for the fall of humanity in western societies (Mottahari, 1989).

So, we may say that the possibility of religious education has been criticized from at least two aspects by those who oppose the possibility of religious education: on one side, because of the role religious education plays in decreasing intellectuality role in and on the other side, its unfamiliarity with the improvement of empirical science and industrial and technological society. Education in the modern world; and on the other side the alienation or ineffectiveness of it for development of experimental science and industrial and technological society. But those pro to the possibility of religious education answering the reasons of those opposing the possibility of religious education, referring to religious literature, have mentioned the high status and position of wisdom and thought in religious education. They believe it is this characteristic gives life and dynamism to the religious education in the present century. The prophets came to extract the reservoirs of wisdom from the internal of humans (NahjolBalaghe, first lecture).

Since human being has spiritual and intellectual dimension, needs religious education for educating this dimension in 
order to have a perfect human being. Otherwise this spiritual dimension doesn't evolve and we will have a half human which is immersed in experimental science with a modern worldview and contradicts his own self. Education is possible for all of us and religion is an intellectual process and activity that every one may enter it and desired educational change is the main objective of all religions.

Islam has considered an important position for wisdom and intellectuality and so intellectuality finds high importance in Islamic education. This is while some western perspectives, especially analytic philosophies against religious education, believe this kind of education lacks intellectuality element and claim that religious education eliminates intellectuality from education process completely and instill that it contradicts liberal education doctrines.

Islamic education is mainly based on intellectual education methods; methods that maintain wisdom balance (purification) and increase the power of argument (philosophy). So intellectuality in Islamic education is at the same time a tool and a goal; so the discussed claims about lack of intellectuality in Islamic education, results from lack of knowledge and lack of complete knowledge from Islamic education or is observed from the cases that religious education has been accomplished by unaware people and with a wrong method.

So Islamic education fruit and benefit is not just embracing religious symbols emotionally, but is a practical mission in whom the person has believed with his wisdom and intellect and confirmed it with his thoughts and emotions; through which he finds the solution of his life problems and illustrative interpretation foe the worldly phenomenon surrounding him. (Ramadan Alboti, 1995). By the way, the possibility of religious education should be sought in the necessity of human beings demand for religion. The demand for religion means the necessity for an orientation model and reference for belief and faith in order to find peace, eternity, stable balance...We may not find anyone who lacks this need. According to Yong, the need for religion is an internal action from psychological- biological point of view. (William James, 1986). In fact, religion is a vital act through which human being finds psychological balance and internal peace. The mentioned hypothesis is completely described by divine philosophers, psychologists and humanists (Karimi, 2002).

\section{The Necessity of Religious Education}

Till now, we have explained some subjects about the possibility of religious education. Now we wanted to know is religious education a necessary element for educating students in schools and universities? When we say religious education must exist, is this must rational? Which rational reasons should be discussed for proving this necessity? Lengford believes whatever is included for learning in order to be real human beings should include education and training, too and interprets this field of education as learning to be human being. The life of human creatures doesn't just involve having a physical structure but participating in human societies and presence in a world of life forms (Karimi, 2002).

Religious education is a control for morality, criterion for individual and social life, growth in educating spirituality and idealism. If religious education is based on right thought, it will lead to development and improvement and rescues human being from drop. Religion is a control 
element for the individual to keep himself away from evils and bothering in society, not harm anyone, people be safe from his hand, tongue and devil and not forget God in social likes and dislikes. Regarding the special and critical conditions of adolescent and his spiritual imbalance because of maturity and the importance of spiritual calmness in this period, we may find the importance of religious education in adolescence period. It is just under the light of religious education that adolescent is rescued from indetermination, ambiguity and confusion of adolescent period, finds a vivid philosophy for himself and may find the answer to his main questions and is guided to a specific orientation in relation to his emotional needs. He may find his real position in the creation under the light of this education, find his character and value it and not commit sin or humiliation. Religious education is vital and necessary for children and we may deal with it from at least two perspectives: individual and social. From individual point of view we should say that religion is the base and essence of all aspects and dimensions of individual life and the cause of many ups and downs.

Islam is the school and religion of education and God, begins his first verses descended to Islam Prophet with the order of reading. "Proclaim! [Or read!] In the name of thy Lord and Cherisher, Who created" (Quran, Al-Alagh: 1). In this verse, we have been ordered to read, with the name of God, the almighty of human being. Islam education system is mainly God, and the extreme of it worshipping God, its book divine message and its student God prophet. In this educational system, education is greatly important, because the first teacher is God, "Taught man that which he knew not" (Quran, Al-Alagh: 6). second teacher is the prophet, "to rehearse to them His Signs, to sanctify them, and to instruct them in Scripture and Wisdom." The prophet has said, I was sent to be a teacher, or, I was sent to complete ethics. So, the importance and necessity of education, especially religious and inherent education, has a special position in this system and school, because individual and social productivity, spiritual and intellectual, moral and physical education, is possible comprehensively just in the light of Islam school teachings and religious education. It is in this case that if a human receives desired education and dominates his own self and knows it and purifies it, may control and adjust his animal and sensual powers and provide the scene for emergence of intellectual, spiritual and innate powers; and with a humanistic- Islamic perspective to others in the society, takes an important step for realization of humanistic- Islamic healthy society. While, "there is no possibility to remain safe from the expansive influences of social forces". (Eisner, 1995).

\section{Education in Secular Societies and the Role of Government}

The title of George Count famous article is related to," have schools the ability to build a new social order? (Ornstein, 1993) stated: "Schools in western societies cannot explain essential and moral values to students as required, because these values root in a society conflicting with each other, since values learnt in schools should be enforced in another place like society. Children just fulfill part of education in school. But these lessons are ignored easily out of school environment." The religion lost human being has in fact lost his divine and human identity. So, he is not only disconnected from God, but also disconnected from his own self, because when he doesn't know God, how he may know himself? He is a captured and in 
crisis person who, in order to acquire his own identity grasps everything, creates ideology and worldview; but he knows himself that this religion and identity is fake; so double restlessness dominates him. Now we observe in many countries that some harmonious people- who are uneducated minority- are in charge of education and guidance of most members of society, and have taken the human essence out of its real identity and have converted it to a false human like identity. It means that they have taken it out of its divine beauty and attractiveness and dressed it up with worldly ornaments. Abu Raja Khamri the $7^{\text {th }}$ century gnostic says: you may see a world in this world full of wounded people and healers more wound than the ill. The education philosophy of countries, according to the requirements of their own made ideologies, seeks one goal: raising people and domesticating them under the title of socialization, acculturation, conformity and conditioning, similarity, adaptability, corresponding norms, become conditioned to the orders and finally being similar with what they expect, i.e. new slavery and this is the same education that has featured in formal education of western countries.

\section{Education in Religious Societies and the Role of Government}

Religious education in West is mostly along emotional, social, cognitive and behavioral education and means teaching special religious ceremonies and rituals, but in Islam it is more expanded and is along other educations. Islamic education in this meaning, gives direction to prevalent doctrines, goals and practices and involves different spheres of physical, psychological, cognitive, emotional and behavioral which regarding the topic of this article, we may address Islamic societies here in detail.
Islamic societies: the duty of protecting religion is one of the most important and difficult duties of Islamic governments; because most distortions come from governors and power owners and this is when governors confront a reality named religion. On the other hand, religious education of future generation is itself an important part of protecting religion. According to insight bases and Islam religious education, government is not per se an ultimate goal, but it is a tool that should implement divine rules and government. From this aspect, religious government or Islamic government is the same as Islamic law sovereignty. In this perspective, government is responsible for religion and people beliefs and cannot remain carless or impartial. So, the executors of this religious government should do their best so that system building, structure building, organizations arrangement, rule- making, exertion of micro and macro managements and also cultural, social and economic policy making should take place according to Islamic worldview and cognitive bases. This doesn't mean not paying attention to unstable conditions of society in national and international levels and ignoring society benefits. So religious government executors are not permitted to integrate and combine religious law structure and based with the bases of other human and unreligious schools and then using arguments like the requirements of modern world or the conditions of contemporary world, deliver it to the society under names like modernity, and new thinking in religion. At the same time they are responsible to use the most new human accomplishments in technology and science domain keeping their intellectual and cultural independence; so religious scientists ought to adapt Islam theory with life, which is the main 
objective of Ijtehad (deducing facts from Quran and Hadis), and show the efficiency and power of Islam in answering humane demands. The main goal of prophets' mission is to educate the society, raise the knowledge and insight of people and improve the social, political and moral affairs of the society in the path of cognition, and God servitude. These objectives are established in the frame of duty for Islamic governors. Imam Ali believes this is the main duty of Islamic government and says: I must train you in different subjects to raise your awareness, so that you won't commit ignorance and depravity and train you in the way you learn how to live. Religious government executors are responsible for providing science and knowledge of the citizens in their government domain. They ought to provide the scene for acquiring knowledge and raising the awareness of people in different fields. Verses like "It is He Who has sent amongst the Unlettered a messenger from among themselves, to rehearse to them His Signs, to sanctify them, and to instruct them in Scripture and Wisdom,- although they had been, before, in manifest error" (Quran, AlAlagh: 2) show the duty of religious government executors in obeying the prophetic mission philosophy.

Mass of people, deprived from worldly power and constitute the majority of society, are mostly under the influence of political and social movements. On the other hand, those people have more influence on this class who enjoy a special status and position in the society. Whether their position is right or wrong has not much influence on decision-making of most people, but it is important how much the influential class enjoy the social, political and economic status and position; because the higher the position and status, the more influential it will be. So, if the influential class is reformist and takes the right path, it will guide people on the right way and if it is corrupted like pharaoh, may lead people to the wrong path resorting to his power and toughness, or like Moavieh, alienate people from divine religion and right way through deceiving them.

Those who are located on the top of society pyramid (for every reason) will really be the model of people in every aspect. Their behavior and speech defines how to live for people, and their thought and mind specifies the orientation of beliefs and cognition of people. This is what we observe in our today society and doesn't need to be proved. When the heads of the society do so much contribute in shaping the character of people, their influence on religiosity of people is undeniable. This nice word, "People obey the religion of their princes" (Alarbli, 2000). Whatever religion do the leaders of society believe in; the people obey it, too. Imam Ali says, people don't obey any one as much as they obey their leaders and governors. So their speech and behavior is so much like their governors and not their fathers.

The Necessity or Unnecessary for deSchooling from Religious Education in Iran

Religious education is kind of intellectual and cultural transition in the cultural structure of a society that emerges in the behavior of person or society. Sociologists believe school is an influential element in shaping human personality, so the values and norms more emphasized at home are consolidated and reinforced at schools (Cohen,1993). The founder of Islamic republic of Iran believes education and university are centers for prosperity and at the same time wickedness of a nation, (Moosavi Khomeini, 1999). As we know, the background of Iran formal education is 375 | Page 
not based on religious teachings and Islamic philosophy and has been under the influence of foreign agents and so directed toward their benefits, while "The way of educating a new generation is one of the main principles dominating the development of a country. Investing in religious education of the people in a society in fact shows the civilization of that society and ensures development in different aspects of a society. So the authorities are obliged to provide doctrinal and healthy education programs to prepare the condition for realization of the desired situation for bringing up a faithful generation" (Ansari, 2001). Along it, the internal concern and continuous distress of those worried for religion and religious teachings, is to bring up the new generation of the society as a generation faithful to values and agent of moral virtue and divine commands. We all know the importance of religious education and believe that if people of the society define their lives according to religion and belief in God, the health and prosperity of the society is assured in political, social, economic, and cultural dimensions. The society who thinks and behaves according to religion, is a society that honesty and truthfulness, liberality and generosity, affection and kindness, love and sincerity, self- sacrifice and forgiveness, independence and freedom, production and fertility, art and artistry, and many other virtues overflow in it and people feel real prosperity and progress of themselves and the society in every second (Karimi, 2001).

In the third millennium, religious revival is viewed with a new attitude in order to be specified what has excited the mass mind to religious beliefs. Now, in modern technology era, a new round of religionist and God-orientation has been thought and acted upon. The third millennium goes in a way in which belief in religion and revival of motivation and religious rational is located on its first platform. May it is why this millennium is called the millennium of religionist, and emergence of great culture and civilization. The report of Gallop international institute of mind evaluating in 1988 showed that more than $90 \%$ of adolescents and youth in America have asserted that they believe in God. 95\% of 13-18 years old respondents believe in God and had religious activities just one week before responding the questions of that investigation. They believed religious faith is an important issue in life (Hakimi and Qamus, 2003).

Now that religion orientation has begun among mass of people in the world, most scholars of education believe that we should propel children and adolescents to being like God. We should be careful that religious education is an expanded concept and includes all dimensions of life and if there is impairment in any part of human life, internal or external, will lead to realization or not realization of religious education. Some affairs are seriously and essentially important and should receive more attention. Islamic Republic of Iran education, too, has defined the objectives completely and comprehensively, inspired by the educational teachings of Islam in different individual and social aspects including ideological, moral, political, cultural, artistic, scientific, economical and biological (rc.majlis.ir). The above goals show that integrated education, has been the opinion of educational system authorities, and educates all dimensions of human existence and all these show the prominent position of education in Iran Islamic Republic system. It is the teacher, school and parents' responsibility to acquaint students with the mentioned objectives and fulfill their duty to reach the 
mentioned goals. From elementary school to the end of high school, students study subjects like Islamic education, Islamic training and the history of Islam and get familiar with religious discussions. And serious studies of these subjects have intensified after the Islamic revolution, and through Education ministry.

And we know that in order to get rid of all kinds of wonders and disappointment and reach real happiness and perfection we should walk in the light way of divine education and it is obvious that paying enough attention to education and especially religious education has an important role in understanding and protecting human position and guiding him to prosperity.

So, as was discussed in Islamic societies, the governors of the society cannot remain irresponsible to religious education of society individuals and according to the teachings of Islam, it is the obligation of rulers and governors to attempt doing it so education ministry as a public institution should undertake this duty and schools will be responsible for delivering religious education to students, so the necessity of de-schooling is rejected in Islamic Republic of Iran. It is necessary that all institutions, organizations and related ministries, families, mass media and publications, corresponding education system plan and move in this direction. Since we shouldn't ignore any factor even not influential.

\section{The Possibility or Impossibility of de- Schooling in Iran Schools}

Most thinkers have approved philosophical possibility of religious education in schools. For example, baldly believes that everyone knows religious or faithful education is not only possible but is really fulfilled in other schools and places (MalekNia, 2001).
In 1970s, different reports showed that the level of school influence on change in society is very lower than it was assumed. In this condition, Ivan Illich's ideas have attracted the attention of many people (Sharepour, 2010). Ivan Illich is a scientist who has made studies related to different fields of religion and especially Christianity and their intellectual background. Because of his interest in studying philosophy and divine science and such, he goes to church and wears priests' dress. He has studied different aspects of subjects discussed in cognitive sociology, and education. Considering his image from religion and school institutions in which he had studied in it till that time, he concludes that these institutions are practically agents to increasingly alienate people. His main idea was that institutions constituting the main elements of society are in fact agents of distortion and even destroying the objectives and institutions which have themselves been created because of them. For example, church is the agent of religion destruction and school the agent for destroying education. Illich calls them distorting and addicting institution. He demands de-schooling from the society and desires a revolution could break the link between formal education and future employment of the individual (Hurn, 1985).

His popular article called school: the sacred caw was one of his first works in education field. In this article, he attacks education very hard and questions it, since education has been trapped in centralization, internal bureaucracy, dogmatism and a place for inequalities. The collection of his articles and lectures has been published under the name of deschooled society.

He believes schools which cannot help students know themselves better or act as bases for his true personality and attain 
cognitive growth through programming and manipulation is not a real school and in a critical view, appeared in de-schooled society, this education doesn't have the power to educate its students comprehensively. The criticism of Illich from Latin America and other American schools may hold about Iranian schools, too. He believes real knowing originates from presence and active participation in significant situations. Looking to Iranian schools indicates that schools don't have any significant situation for education and what is acquired from study process, is nothing except mental injury and practical loss of society children. From Illich's perspective, school sells curriculum and the result of producing curriculum process is something like other productive goods of modern world. In education process, teacher is the distributor of the final result to the customer or student. Illich believes school is an effective institution to transfer those ideas and values which he disapproves and on the contrary those ideas and values he admires are ineffective. In his opinion, Catholic Church asserts that has the monopole of acquiring salvation, contemporary schools claim that they have the monopole of cognition and knowledge in their hands. Illich, like Pavlov Ferire the Brazilian intellectual believes that mandatory formal education instead of increasing cognitive and intellectual growth destroys the intellectual independence of child. This intellectual independence may be acquired just outside mandatory formal education (Hurn, 1985).

He believes the only way is to abolish the mandatory formal education and substitute it with a network of special institutions to reinforce the real objectives of education. People should be permitted to attend any of these centers they want. Government shouldn't make children to attend in school and more important, employers shouldn't require level of study, grades, certification and such, instead they should employ people according to their qualifications, (Illich, 1971).

Foucault is another thinker opposing school. He claims in institutions like school, prisons, hospitals and workshops, special disciplinary techniques is employed and in their frames some regulations governed behavior and actions of people and some attempts for caring and methods for supervising them was compiled and employed. The life of students, soldiers, patients and prisoners is cared, supervised and used for report preparation and normative behavior is encouraged and undesired behavior receives punishment. The ultimate aim is care for, supervise and discipline, normalizing the person and eliminating social and psychological undisciplined people and finally educate obedient, and beneficial people in the society and in the service of powerful rulers.

He says interpretations like selffounded, self-confident, etc. in educational systems and social thoughts are masks used to continue power in new forms. From Foucault's point of view, norms established, accompanied by tests, classifications, encouragements, compensations, required location and disciplinary punishments, all comprise different aspects of authority in school. In this case, it is obvious tests are very important and exert one's individual identity to him. Educational needs and the tendencies of child in liberal education which is emphasized very much is nothing except values and norms of disciplinary block of the school required to shape the identity of children .As a result, children become something that school educational needs and interests classification makes from them and proceed to the same 
objectivity assumed by science (Foucault, 1999).

In this way, scientists like Ivan Illich and Foucault, not only believe school isn't a current in the same direction as real education, but desire new conditions. Ivan Illich believes de-schooling is an essential solution and explains its philosophical possibility. He believes any kind of education, religious, social and etc. shouldn't be assigned to school, because it is anti-educational, and students believe education is boring and not related to their interests.

Islamic Republic of Iran presents a new model of educational curriculum in response to the demands and requisitions of Islamic dynamic society and according to the principles, values and objectives of Islamic education and utilizes the local and national potencies and benefits from valid and successful experiences in the world which is considered as an important step along documentation and qualification of education system of Iran. Paying attention to the transcendent educational objectives and diverse demands of learners and society is considered to educate a first class person for Islamic republic of Iran. The principles governing the national curriculum production process is classified in 9 categories. In the introduction of education system's primary document, we read: "Realization of the transcendent values and goals of Islamic Revolution requires comprehensive effort in all cultural, scientific, social and economic dimensions. Acquiring the education scene is one of the main transcendence infrastructures and comprehensive progress of the country and serious tools to enhance qualified human capital in different domains". So, realization of Islamic revolution transcendent objectives requires educating scholar, virtuous, liberal and ethical persons; the education that realizes the pure life, world justice society and Iranian- Islamic civilization. It is under the light of such transcendent human capital that human society will be ready to realize a comprehensive human world government and it is under the shadow of this government that capabilities and talents of person will attain florescence and perfection. National curriculum, as an important document of fundamental change program, plays important role in establishment and operationalization of the objectives of this plan.

The main objective of fundamental change in education is to present Islamic education system, so that the youth brought up by this system could attain the qualified perfection under the light of Islamic educational teachings and experience the pure life better than the past and reach to the prosperity of this world, build their own country and be prosperous in the other world. National curriculum document is also the operational essence of Islamic education philosophy documents. This plan has special intellectual sanctuaries; it means it has philosophical foundations of existence knowledge, epistemology, human knowledge, value knowledge, psychology and sociology; and its standard and validated system, is the divine message and intellect. The content section of national curriculum has introduced 11 learning areas in which each are is responsible for one field of our generation life grounds, and we should provide possibilities and material and human resources to contribute the transcendence and florescence of the individual's talent in that field. In fact what is introduced under the name of national curriculum is a comprehensive and massive map of the road and naturally its language is abstract and general and by producing subsystems 
and programs of every field in every course, the language becomes more objective and operational. So national curriculum and fundamental change plan seeks education that realizes the pure life and is the introduction of Mahdavi world justice society and Islamic civilization. It is under the light of this government that the capabilities and talents of human being will attain florescence and perfection.

In religion knowing principles section of the national curriculum document, we read: this class of principles mentions discussions about the position of Islam and its educational goals related to curriculum. Explaining these propositions is necessary because pure Islam teachings - as the right religion-is applicable is all parts and elements of curriculum like the ultimate goal of human education, its perspective to the teacher, curriculum content, learningteaching methods, the position of teacher and trainer, educational materials and evaluation methods.

In sociological foundations we read, education institution, is the main part of culture and interacts other institutions and is obliged to play its educational mission correctly while responding the society demands and social requisitions.

National curriculum attitude is inspired from following principles and has the following characteristics:

It has a comprehensive and perfect view to the human being and considers his spiritual and physical growth; prepares the ground for florescence of human divine nature, provides the ground for satisfaction of God from human being and human being from the divine formative will.

So our country's formal education is directly administered by government; as it was mentioned in the national curriculum document, the aim of education is to educate comprehensively a religious obliged person; so we may not separate students' religious education from school. So the possibility of de-schooling from religious education in Islamic republic of Iran is denied.

\section{Conclusion}

Scientists like Ivan Illich and Foucault, not only believe school isn't a current in the same direction as real education, but desire new conditions. Ivan Illich believes de-schooling is an essential solution and explains its philosophical possibility. He believes any kind of education, religious, social and etc. shouldn't be assigned to school, because it is anti-educational, and students believe education is boring and not related to their interests.

Our country's formal education is directly administered by government; as it was mentioned in the national curriculum document, the aim of education is to educate comprehensively a religious obliged person; so we may not separate students' religious education from school. So the possibility of de-schooling from religious education in Islamic republic of Iran is denied.

In Islamic societies, the administrators and politicians cannot be irresponsible for the religious education of members of their society. According to the doctrines of the true religion, Islam, governors and politicians are obliged to attempt to accomplish this affair, so ministry of education as a public institution has taken the charge of this affair and schools are charged with delivering religious and divine education to the students and the necessity of deschooling the religious education is denied in Islamic republic of Iran.

Nowadays, education system of Islamic society is susceptible to doubt and vagueness from two aspects. If in some societies there is doubt toward ethical and 
value education and especially religious and faithful moral education, it is not necessarily because of doubt in the necessity of moral education, but because of doubt in the possibility of realization of true ethical and value education, and this doubt has been originated from existing weaknesses and deficiencies in attitudes and methods of ethical and value education. So precise clarification of attitudes and methods of moral and ethical education may contribute to eliminate the existing vagueness and doubts and create enough motivation for paying attention to ethical and value education. Finally it seems that in Islamic republic of Iran, discussion about the possibility and necessity of religious education in schools, while approved by Education ministry but requires some arrangements. Unprofessional and inefficient authorities, lack of appropriate understanding education, lack of clear philosophy for Islamic and religious education, gap between theory and action, lack of aesthetic discussions and considerations in religious education will bring lots of trouble in this issue, considering this essential point that why seculars have seized religious education, and why from their point of view this education brings artificial behaviors and conflict, instrumental use of religion and misunderstanding religion, misunderstanding nature and essence of religious education, lack of desired religious education model, lack of religious education theory, drawbacks in teaching methods area, lack of religious education teaching skills, and it is seen that we suffer from lack of scientists and experts in administration and theory making arena. On the other hand some kind of religious, philosophical and scientific dogmatism dominates Iran schools. Dogmatism is a large barrier on the way of intellect and thought. For instance we should permit thinking about other religions, too, and so decreasing dogmatism confrontation with religions, philosophies and sciences contributes to this goal. It is evident that this attitude requires a plan which doesn't permit education system imbalance which leads to imbalance in religious education programs; this is while this imbalance is observed in educational plans of education systems in Islamic societies.

\section{References}

Alarbli, A. (2000). Kashf-el-Ghama-fiMaarefate- Al-Aema, Qom: Razi publication.

Ansari, T. (2001). Essential techniques and efficient methods in education planning to acquire suitable education for students. Presented at the Conference of Religious Pathology in Education. Tehran.

Cohen, B. (1993). Sociology Foundations, Transl. Tavssoli, Gh, Fazel, R, Tehran: Samt Publications.

Dawey, J. (1960). Democracy and Education, Transl. Aryanpoor, A, Tehran: Shafaq publications.

Eisner, EW. (1990). The Educational Imagination, New York: Prentice Hall.

Focualt, M. (1999). Care and punishment: birth in prison. Transl Jahandide, A, Sarkhosh, N, Tehran: Nei publications.

Hakimi, M, Kamus, M (2003). Children and adolescent literature foundations. Vol.1. Tehran: Aron.

Holy Quran

Hurn, C0, (1985). The Limits and Possibilities of Schooling: An Introduction to the Sociology of Education, Boston: Allyn and Bacon. 
Illich, I. (1971). The Breakdown of Schools: A Problem or a Symptom? Interchange, 2:1-10.

James, W. (1986). Religion and Soul, Transl.. Ghaeni, M, Tehran: Book Translation and Publication institute.

Karimi, A. (2001). Religion giving or religion finding, Islamic education, special for religious education pathology. Qom: Islamic education studies center.

Karimi, A. (2002). A symbolic Attitude to Religious Education Emphasizing Explorative Methods. Tehran: Ghadyani publication.

Maleknia, A. (2001). Clarification and analysis of possibility and necessity of religious education to suggest suitable techniques for religious education, M.A thesis, Islamic Azad University, Tehran.

Malssen, T.v. (2015). The Political Philosophy of Francis Bacon, New York: Suny Press.
Marzooghi, R. (1997). Paige \& Kleberg Ethical Development Theory, Tarbiat, 124: 41-43.

Moosavi Khomeini, R. (1999). Sahife-Noor, vol. 1. Qom: Compose and Publication of Imam Komeini's works.

Mottahari, M. (1989). Collection of Works. Tehran: Sadra Publications.

NahjolBalaghe (2008). Transl. Jafari, M.T. Qom: Ialami publication.

Ornstein, A, Daniel L. (1993). Foundations of Education. Boston: Houghton Mifflin Company.

Ramadan Alboti, M.S. (1995), Islamic teaching experience in Mizan Al- Bahs, Beyrouth: Farabi.

Sharepour, M. (2010). Education sociology, Tehran: Samt.

How to cite this article: Seyed Mahdi Sajjadi, Sareh Ansari, Deschooling from Religious Education in Islamic Republic of Iran: Possibility and Necessity? International Journal of Advanced Studies in Humanities and Social Science, 2019, 8(4), 369-382. http://www.ijashss.com/article_84385.html 